\title{
Thomas J. Berghuis, Performance Art in China, Hong Kong, Timezone 8 Limited, 2006, 310 pp.
}

\section{Emmanuel Lincot}

\section{(2) OpenEdition \\ 1 Journals}

\section{Electronic version}

URL: http://journals.openedition.org/chinaperspectives/3553

DOI: 10.4000/chinaperspectives.3553

ISSN: 1996-4617

\section{Publisher}

Centre d'étude français sur la Chine contemporaine

\section{Printed version}

Date of publication: 1 January 2008

Number of pages: 118-119

ISSN: 2070-3449

\section{Electronic reference}

Emmanuel Lincot, « Thomas J. Berghuis, Performance Art in China, Hong Kong, Timezone 8 Limited, 2006, 310 pp. », China Perspectives [Online], 2008/1 | 2008, Online since 01 January 2008, connection on 22 September 2020. URL : http://journals.openedition.org/chinaperspectives/3553 ; DOI : https:// doi.org/10.4000/chinaperspectives.3553

This text was automatically generated on 22 September 2020.

(c) All rights reserved 


\title{
Thomas J. Berghuis, Performance Art in China, Hong Kong, Timezone 8 Limited, 2006, $310 \mathrm{pp}$.
}

\author{
Emmanuel Lincot
}

1 Performance Art in China is a major work published by Robert Bernell, founder of Timezone 8 publishers and owner of a bookshop at Dashanzi in Beijing. Written by Thomas J. Berghuis, a young researcher who worked with the guidance of Australian Sinologist John Clark, this is the first book on a largely unknown subject, and consists of an introduction and eight chapters replete with often rare illustrations, an extensive chronology, an index highly useful for looking up artists' names both in Pinyin and in Chinese characters, and a bibliography revealing the remarkable amount of work the author put in. Berghuis has gleaned much information from the renowned art critic and event organiser Li Xianting, as well as from the late Hans Van Dijk, who with the help of the artist Ai Weiwei set up an art archive and warehouse in Beijing tracing China's artistic evolution over the last quarter century.

2 Although it may seem to be floating in detail, this is in fact an enthralling study. Performance art is a form of intervention that involves working with one's own body and showing oneself physically during a private or public demonstration. In fact, the word "performance," which in English has the sense of a show or a representation and which in Mandarin Chinese is referred to as biaoyan yishu, is now used to refer to all artistic activity that takes place in front of onlookers and is accompanied by music (sound art), dance, poetry, theatre, or video, or contains some combination of these elements. Berghuis notes historical precedents of performance art in the West and their links to other modes of expression: body art, happenings, and Fluxus (flow) events. The most salient aspect of this book is that it shows how in both the West and in China aesthetics are overshadowed by ethical concerns. Thus it is no longer a matter of erecting a cult of beauty, but of seriously questioning the inherently arbitrary nature of collective values or the circumstances of daily life. It is sociology in action. 
This aspect is illustrated by the choice of the book's own cover art, which shows a famous 1985 painting entitled Triple Mao Zedong by Ai Weiwei, along with a photograph of the performer Ma Liuming between the renowned British performance artists Gilbert and George, labelled "living sculptures" and taken in Beijing's East Village in 1993. Between the creation of these two images, which complicate the thesis argued by Berghuis, the events of 1989 occurred. Apart from the crackdown against demonstrators in Tiananmen Square on June 4, that year also saw an event on February 5 that was of considerable importance in Chinese artistic history: the censoring of the national exhibition of "experimental art" (shiyan meishu) featuring a performance by artists Tang Song and Xiao Lu during which Xiao fired on their installation, a telephone kiosk ironically called duihua ("dialogue"). It anticipated the impossibility of communication between civil society and the authorities and was definitively translated by the literal application of the young Mao Zedong's dictum in April 1917: "In order to civilize the mind one must first make savage the body." Retrospectively, the event also presaged the abandonment by a growing number of artists of painting as a system (with its institutions, practices, models, discourses, and economics), as well as their rejection of the veritable secular cult that obliged art to seek answers not as evidence but from the viewpoint of critical anthropology.

Berghuis does not delve deeply into these aspects, nor does he explore an important precedent, the Gutaï movement in Japan in the 1950s. It would have been worth knowing if the Gutaï group had any influence on the performance artist Kwok Mangho, who went to Beijing in the 1970s during the first Chinese avant-garde wave represented by artists such as those in the Stars Group (Xing Xing pai). Berghuis mentions the ideas of Georges Bataille, especially the notion of "dépense" or unproductive expenditure, which seeks to justify the artistic initiatives of several generations in China subjected to physical tests in their rapport with the authorities. The reference to Bataille is pertinent, given the fascination he had for the infamous 1905 photograph by Louis Carpeaux of a Chinese torture victim, which shocked him with a veritable revelation of eroticism lighting up a face writhed in agony. But the parallel ends there. Zhu Yu's Pocket theology (January 1999), showing a severed arm bought cheaply from a morgue in Beijing, might certainly assert - in the manner of a Bataille - the power of a negativity that is not a passage towards a true positiveness, and which is incapable of striking a rapport between the present and the past and thus of articulating a new present.

5 Meanwhile, a huge majority of Chinese artists belong to one or more affiliations that form a mosaic of tonalities ranging from a claim to Dadaism to its rejection through heuristic violence. This claim might also take the form of recourse to the longest tradition - that of Daoism - as well as to the most recent, namely the Cultural Revolution, that traumatic Maoist episode that Berghuis has no hesitation in comparing to the post-war European environment that gave rise to the German artist Anselm Kiefer. 